\title{
PENGARUH PRESTASI KERJA, PENDIDIKAN, PENGALAMAN KERJA, PENGENALAN, DAN KESEMPATAN UNTUK TUMBUH TERHADAP PENGEMBANGAN KARIR PEGAWAI NEGERI SIPIL PADA KANTOR DINAS KETENTRAMAN KETERTIBAN DAN SATUAN POLISI PAMONG PRAJA
}

\author{
Suratman Hadi
}

\begin{abstract}
ABSTRAK
Tujuan penelitian ini adalah untuk menganalisis pengaruh prestasi kerja, pendidikan, pengalaman, pengenalan, dan kesempatan untuk tumbuh secara simultan ataupun parsial terhadap pengembangan karir pegawai negeri sipil, dan untuk mengetahui variabel mana yang paling dominan mempengaruhi pengembangan karir pegawai negeri sipil tersebut. Pengumpulan data dilakukan melalui wawancara, observasi, studi dokumentasi, dan kuesioner. Populasi penelitian ini adalah pegawai negeri sipil pada Kantor Dinas Ketentraman Ketertiban Dan Satuan Polisi Pamong Praja Kota Denpasar. Sampel di ambil secara stratified random sampling sebanyak 61 responden. Hasil penelitian menunjukkan bahwa prestasi kerja, pendidikan, pengalaman kerja, pengenalan dan kesempatan untuk tumbuh secara simultan berpengaruh terhadap pengembangan karir pegawai negeri sipil, sedangkan secara parsial hanya variabel Pendidikan, pengenalan dan kesempatan untuk tumbuh yang mempunyai pengaruh terhadap pengembangan karir pegawai negeri sipil di mana variabel yang paling dominan pengaruhnya terhadap pengembangan karir pegawai negeri sipil adalah variabel pengenalan. Implikasi dari penelitian ini bahwa dalam meningkatkan karir PNS perlunya setiap pegawai untuk mengenalkan diri kepada pejabat wewenang yang memutuskan dalam peningkatan karir pegawai serta melibatkan diri secara aktif pengembangan karir pegawai negeri sipil pada kantor Dinas Ketentraman Ketertiban dan Satuan Polisi Pamong Praja untuk kegiatan presentasi yang dilaksanakan di dalam maupun di luar organisasi, baik sebagai peserta maupun pembicara.
\end{abstract}

Kata Kunci: Pengembangan Karir Pegawai Negeri Sipil

\section{PENDAHULUAN}

Karir adalah seluruh jabatan yang diduduki atau ditempati seseorang dalam kehidupan kerjanya (Rivai,2011:264). Untuk orang-orang tertentu jabatan-jabatan ini adalah tahapan-tahapan dari suatu perencanaan yang cermat walaupun beberapa faktor mengungkapkan ini merupakan semata-semata dari keberuntungan. Meskipun seseorang sudah menyusun perencanaan karir tidak menjamin karirnya menjadi berhasil. Ada beberapa peran-peran penting dalam menunjang kesuksesan seseorang yaitu kinerja yang 
unggul, pengalaman, pendidikan, keahlian dan keberuntungan. Hal-hal yang berkaitan dengan pengembangan karir seorang karyawan atau pegawai yaitu prestasi kerja (job performance), pengenalan (exposure), jaringan kerja (net working), pengunduran diri (resignations), kesetiaan terhadap organisasi (organizational loyality), pembimbing dan sponsor (mentors and sponsors), bawahan yang mempunyai peranan kunci (key subordinates), peluang untuk tumbuh (growth opportunies), pengalaman (experience) (Rivai, 2011:274-279). Penelitian Rosyawati (2007), Tujuan dari penelitian ini adalah untuk menganalisis pengaruh prestasi kerja, pengenalan, kesempatan untuk tumbuh, pendidikan dan pengalaman kerja terhadap pengembangan karir pejabat perempuan di Pemerintah Provinsi Bali. Hasil penelitian menyimpulkan bahwa prestasi kerja, pengenalan, kesempatan untuk tumbuh, pendidikan dan pengalaman kerja berpengaruh secara simultan sedangkan variabel prestasi kerja, pengenalan, dan kesempatan untuk tumbuh berpengaruh secara parsial terhadap pengembangan karir pejabat perempuan di Pemerintahan Provinsi Bali.

Dinas Ketentraman Ketertiban dan Satuan Polisi Pamong Praja (Dinas Tramtib dan Sat-Pol PP) merupakan dinas yang membantu kepala daerah dalam menegakan peraturan daerah dan peraturan kepala daerah, serta menyelenggarakan Ketentraman dan Ketertiban Umum. Pelayanan yang diberikan berupa penyusunan program dan pelaksanaan ketentraman dan ketertiban umum, penegakkan Peraturan Daerah (Perda), dan penegakan Peraturan Kepala Daerah pelaksanaan kebijakan pemeliharaan dan penyelenggaraan Ketentraman dan Ketertiban Umum di daerah pelaksanaan kebijakan, penegakan peraturan daerah dan peraturan kepala daerah, pelaksanaan koordinasi pemeliharaan penyelenggaraan ketentraman dan ketertiban umum, penegakan peraturan daerah, peraturan kepala daerah dengan aparat kepolisian negara, pengawasan terhadap masyarakat agar mematuhi dan mentaati peraturan daerah dan peraturan kepala daerah. Hasil wawancara dan observasi yang yang dilakukan hanya sebagian kecil pegawai yang datang terlambat saat jam datang dan jam pulang serta ijin karena suatu hal. Jadi dapat dipastikan bahwa secara mayoritas pegawai negeri pada Dinas Tramtib dan Sat-Pol PP Kota Denpasar selalu mengutamakan kedisiplin kerja dalam pelaksanaan tugas-tugasnya. Penelitian Harlie (2010), menunjukkan bahwa kinerja Pegawai Negeri Sipil Pada 
Pemerintah Kabupaten Tabalong Di Tanjung Selatan variabel yang paling berpengaruh yakni variabel displin kerja memiliki nilai tertinggi dibandingkan dengan variabel bebas yang lain yaitu variabel motivasi kerja dan variabel pengembangan karir, maka displin kerja di kantor Pemerintah kabupaten Tabalong di Tanjung Selatan mencerminkan tingkat prestasi kerja yang tinggi. dilakukan pada kantor Dinas Ketentraman Ketertiban Dan Satuan Polisi Pamong Praja Kota Denpasar setiap pegawai yang telah diangkat menjadi PNS, tidak semuanya mengenyam pendidikan di bangku perkuliahan. Banyak dari mereka yang merupakan lulusan di tingkat SLTA dan sederajatnya. Pengangkatan mereka sebagai PNS merupakan hasil jerih payah mereka setelah masa pengabdian sekian tahun. Inilah yang menjadi tolak ukur kinerja pegawai pada Dinas Tramtib dan Sat-Pol PP Kota Denpasar dalam penempatan tugas- tugasnya. Tingkat pendidikan pegawai yang kurang sesuai dengan penempatan tugas seringkali menjadi masalah yang berarti karena pada instansi seperti Dinas Tramtib dan Sat-Pol PP Kota Denpasar memerlukan pegawai yang memiliki kualifikasi dengan keahlian khusus untuk dapat bisa bekerja baik untuk bagian administrasi maupun untuk di lapangan. Semua pegawai pasti pernah mengalami keadaan berupa promosi (kenaikan jabatan), demosi (penurunan jabatan) maupun mutasi (perpindahan jabatan). Ketiga keadaan ini menjadi suatu siklus pekerjaan yang harus dijalani oleh setiap pegawai pada umumnya yang bekerja di lingkungan pemerintah Kota Denpasar dan pada khususnya bekerja di lingkungan Dinas Tramtib dan Sat-Pol PP Kota Denpasar. Kenaikan jabatan (promosi), penurunan jabatan (demosi) maupun perpindahan posisi jabatan (mutasi) merupakan hasil kerja yang ditunjukkan bagi pegawai pada periode tertentu. Sejalan dengan perubahan penempatan, pengalaman kerja pun semakin beragam. Namun pada Dinas Tramtib dan Sat-Pol PP Kota Denpasar tiap tahun selalu diadakan mutasi intern. Mutasi ini mengakibatkan sedikit kekacauan dalam kegiatan bidang organisasi khususnya bidang administrasi. Dalam satu tahun belum tentu setiap pegawai dapat menguasai setiap pekerjaannya dengan cakap dan baik. Oleh karena itu, sering terjadi kesimpangsiuran untuk setiap tugas baru yang didapat setiap tahunnya.

Awal pelaksanaan pekerjaan, selalu terjadi kesalahan akibat perubahan prosedur pekerjaan yang terlalu cepat kurangnya diimbangi dengan berbagai pengenalan berupa sosialisasi serta pengetahuan tentang pekerjaan tersebut, maka dalam kesempatan untuk 
tumbuh bagi seorang pegawai dapat ditempuh dengan mengikuti berbagai pelatihan, kursus, bimbingan teknis serta diklat, karena dengan itu seorang pegawai dapat mengembangkan pengetahuan dan wawasannya tentang berbagai hal yang menyangkut bidang yang ingin dipelajari dan dikuasainya.

Pengembangan karir adalah proses peningkatan kemampuan kerja individu yang dicapai dalam rangka mewujudkan karir yang diinginkan (Rivai,2011:265). Beberapa hal yang berkaitan dengan pengembangan karir seorang karyawan adalah (1) prestasi kerja (job performance), (2) pengenalan (exposure), (3) jaringan kerja (net working), (4) pengunduran diri (resignations), (5) kesetiaan terhadap organisasi (organizational loyality), (6) pembimbing dan sponsor (mentors and sponsors), (7) bawahan yang mempunyai peranan kunci (key subordinates), (8) peluang untuk tumbuh (growth opportunies), (9) pengalaman (experience) (Rivai,20011:274-279). Sedangkan menurut Saydam (2005:560), menyatakan bahwa keberhasilan seorang karyawan dipengaruhi oleh (1) pendidikan formal, (2) pengalaman kerja, (3) sikap atasan, (4) prestasi kerja, (5) adanya lowongan jabatan serta (6) produktivitas kerjanya. Abraham Maslow dalam (Rivai, 2011:840), Hierarchical of Needs Theory bahwa pada setiap diri manusia itu terdiri atas lima kebutuhan yaitu kebutuhan secara fisiologis, rasa aman, sosial, penghargaan, dan aktualisasi diri. David McClelland dalam (Rivai, 2011:840), McClelland theory of needs menganalisis tentang tiga kebutuhan manusia yang terdiri dari kebutuhan dalam mencapai kesuksesaan (Need for achievement), kebutuhan dalam kekuasaan atau otoritas kerja (Need for power), kebutuhan untuk berafiliasi (Needs for affiliation). Dalam penelitian Crowley, et al. (2012), Penelitian ini menyatakan bahwa pengaruh pengembangan karir yang berimbas pada arah karir dalam diri. Dimana pengembangan karir berpengaruh berdasarkan pertimbanggan untuk menumbuhkan ekspatriat diri yang terampil. Nise (2009), pengembangan karir dilakukan untuk mensejahterakan dan memajukan kemampuan karyawan karena karyawan merupakan asset bagi perusahaan.

Prestasi kerja adalah proses melalui mana organisasi-organisasi mengevaluasi atau menilai prestasi kerja karyawan (Rivai, 2011:274). Abraham Maslow dalam (Rivai, 2011:840), Hierarchical of Needs Theory, Kebutuhan aktualisasi diri adalah kebutuhan 
untuk menggunakan kemampuan skill, potensi, kebutuhan untuk berpendapat dengan mengemukakan ide-ide, memberikan penilaian dan kritik terhadap suatu. Rosyawati (2007), hasil menunjukkan, untuk meningkatkan prestasi kerja terhadap pengembangan karir pejabat perempuan di Pemerintah Provinsi Bali, disarankan agar tidak menundanunda pekerjaan dan menyelesaikan tugasnya sesuai dengan jadwal yang telah ditetapkan.

Pendidikan adalah suatu kegiatan untuk meningkatkan penguasaan teori dan keterampilan memutuskan terhadap persoalan-persoalan yang menyangkut kegiatan guna mencapai tujuan. Upaya ini dilakukan untuk memperbaiki kontribusi produktif para karyawan dan mengembangkan sumber daya manusia menghadapi segala kemungkinan yang terjadi akibat perubahan lingkungan (Sutrisno, 2009:62). Abraham Maslow dalam (Rivai, 2011:840), Hierarchical of Needs Theory, Kebutuhan aktualisasi diri adalah kebutuhan untuk menggunakan kemampuan skill, potensi, kebutuhan untuk berpendapat dengan mengemukakan ide-ide, memberikan penilaian dan kritik terhadap suatu. Barbara, et al. (2010), Temuan penelitian menunjukkan bahwa pengembangan karir merupakan elemen penting dari proses pendidikan sebagai siswa yang transisi dari sekolah tinggi untuk mengirim pendidikan tinggi ke pasar tenaga kerja. Studi menunjukkan bahwa siswa yang berpartisipasi dalam program eksplorasi karir lebih mungkin untuk lulus dari sekolah tinggi, dan pencapaian pendidikan yang baik merupakan faktor kunci dalam mengurangi residivisme.

Pengalaman kerja adalah suatu dasar / acuan seorang karyawan dapat menempatkan diri secara tepat kondisi, berani mengambil resiko, mampu menghadapi tantangan dengan penuh tanggung jawab serta mampu berkomunikasi dengan baik terhadap berbagai pihak untuk tetap menjaga produktivitas, kinerja dan menghasilkan individu yang kompeten dalam bidangnya (Sutrisno, 2009:158). David McClelland dalam (Rivai, 2011:841) dalam McClelland Theory of Needs, kebutuhan dalam kekuasaan atau otoritas kerja (Need for power), kebutuhan untuk membuat orang beperilaku dalam keadaan yang wajar dan bijaksana didalam tugasnya masing- masing. Muis (2009), Kriteria dalam pelaksanaan penelitian adalah (1) Responden yang diteliti minimal lulusan SMU, (2) Karyawan tetap, (3) pengalaman kerja minimal 3 tahun. Tujuan penelitian 
yakni dampak positifnya adalah munculnya performansi kerja yang tinggi dengan berusaha untuk mengungguli orang lain dalam mengisi keterbatasan kesediaannya jabatan yang akan diduduki.

Pengenalan/Exposure berarti menjadi dikenal oleh orang-orang yang memutuskan promosi, transfer dan kesempatan-kesempatan karir lainnya, seperti atasan langsung dan pimpinan bagian kepegawaian. Tanpa pengenalan, karyawan yang berprestasi baik mungkin tidak memperoleh kesempatan untuk mencapai sasaran-sasaran pada karirnya. Dimana seorang karyawan akan semakin dikenal oleh para pengambil keputusan dan akan semakin dihargai apabila karyawan bersedia dan sering terlibat dalam berbagai kegiatan sebuah organisasi yang sebenarnya berada diluar tuntutan tugas pokoknya (Rivai, 2011:275). Abraham Maslow dalam (Rivai, 2011:840) Hierarchical of Needs Theory, Kepemilikikan sosial adalah kebutuhan merasa memiliki, kebutuhan untuk diterima dalam kelompok, berafiliasi, berinteraksi dan kebutuhan untuk mencintai dan dicintai. David McClelland dalam (Rivai, 2011:841), McClelland Theory of Needs kebutuhan untuk berafiliasi (Needs for affiliation), hasrat untuk bersahabat dan mengenal lebih dekat rekan kerja atau para karyawan di dalam organisasi. Aurathai, Sirivan, et al. (2009), kompetensi karir memiliki hubungan yang cukup positif dengan kesuksesan karir. Selain itu, kompetensi karir terdiri dari tiga hal, yaitu komputer dan bahasa, kerja tim dan kepemimpinan, dan pengetahuan pariwisata dan perhotelan dan keterampilan berpengaruh pada kesuksesan karir.

Kesempatan Untuk Tumbuh merupakan pengembangan karir seseorang sangat tergantung dari karyawan itu sendiri dalam memanfaatkan kesempatan yang ada untuk karyawan meningkatkan kemampuan, misalnya melalui program pelatihan, pengambilan kursus-kursus atau penambahan gelar, maka berarti karyawan tersebut memanfaatkan kesempatan untuk tumbuh (Rivai, 2011:278-279). David McClelland dalam (Rivai, 2011:841), McClelland theory of needs, kebutuhan dalam mencapai kesuksesan (Needs for achievement) dimana seseorang memiliki keinginan untuk mencapai kesuksesan. Mereka berjuang untuk memenuhi ambisi secara pribadi daripada mencapai kesuksesan dalam bentuk penghargaan perusahaan atau organisasi. Sehingga mereka melakukannya selalu lebih baik dan lebih efisien dari waktu ke waktu. Jessica dan Ronald (2011), 
Dukungan pengembangan karir, fleksibilitas dan otonomi dalam desain pekerjaan serta fleksibilitas dalam perencanaan pengembangan karir muncul sebagai strategi pengembangan karir positif yang akan mempengaruhi persepsi karyawan dari kehidupan kualitas kerja.

Menurut UU No. 43 Tahun 1999 perubahan UU No. 8 Tahun 1974, Pegawai Negeri berkedudukan sebagai unsur aparatur Negara yang bertugas memberikan pelayanan kepada masyarakat secara profesional, jujur, adil dan merata dalam penyelenggaraan tugas Negara, pemerintahan dan pembangunan. Untuk itu diperlukan PNS yang profesional, bertanggung jawab, jujur dan adil melalui pembinaan yang dilaksanakan berdasarkan sistem prestasi kerja dan sistem karir dengan titik berat pada sistem prestasi kerja. Hal ini akan memberi peluang bagi PNS yang berprestasi tinggi untuk meningkatkan kemampuannya secara profesional dan berkompetisi secara sehat. Dengan demikian pengangkatan dalam jabatan di lingkungan pegawai negeri harus didasarkan pada penilaian obyektif terhadap prestasi, kompetensi dan pelatihan yang diikuti Pegawai Negeri Sipil.

\section{METODE PENELITIAN}

Berdasarkan permasalahan yang diteliti, penelitian ini digolongkan pada penelitian asosiatif (hubungan), yaitu penelitian yang bertujuan untuk mengetahui hubungan antara dua variabel atau lebih (Sugiyono, 2012:5). Dalam penelitian ini jenis hubungannya adalah hubungan linier karena bertujuan mengetahui pengaruh variabel bebas (prestasi kerja, pendidikan, pengenalan, pengalaman dan kesempatan untuk tumbuh) terhadap variabel terikatnya (pengembangan karir).

Penelitian dilakukan pada Dinas Ketentraman Ketertiban Dan Satuan Polisi Pamong Praja. Beralamatkan di J1. Jalan Kecubung I No. 4 Denpasar, Telp: (0361) 228713. Jenis data yang digunakan dalam penelitian ini adalah data Kuantitatif dan data Kualitatif

Pengumpulan data menggunakan metode wawancara, kuesioner, studi dokumentasi, dan observasi. Sampel diambil dengan menggunakan metode penarikan sampel statifilasi (stratified random sampling) dimana dalam metode ini digunakan 
kriteria yang jelas akan digunakan sebagai dasar penentuan strata (kelas/kelompok/lapisan) dan melibatkan responden sebanyak 61 orang pegawai. Tahapan analisis data dilakukan melalui uji instrument penelitian menggunakan uji validitas dan reliabilitas, uji asumsi klasik, analisis korelasi berganda, analisis regresi berganda, dan uji koefisien betha.

\section{HASIL DAN PEMBAHASAN}

Uji validitas untuk variabel pengembangan karir, prestasi kerja, pendidikan, pengalaman kerja, pengenalan, dan kesempatan untuk tumbuh dikatakan valid karena nilai koefisien korelasinya (r) 0.3 setiap item pertanyaan memiliki koefisien korelasi berkisar 0.405 sampai 0.919 .

Pengujian reliabilitas instrument pada variabel pengembangan karir, prestasi kerja, pendidikan, pengalaman kerja, pengenalan, dan kesempatan untuk tumbuh dikatakan reliable karena nilai alpha cronbach lebih besar dar $\mathrm{r}$ table 0.60 setiap variabel memiliki alpha cronbach sebesar 0.666, 0.734, 0.737, 0.745 0.763, 0.764, 0.767, 0.827, $0.841,0.872$.

Teknik analisis korelasi berganda digunakan untuk mengukur tinggi rendahnya hubungan simultan antara prestasi kerja, pendidikan, pengalaman kerja, pengenalan dan kesempatan untuk tumbuh terhadap pengembangan karir. Teknik analisis determinasi dipergunakan untuk mengetahui variasi hubungan secara simultan antara prestasi kerja, pendidikan, pengalaman kerja, pengenalan dan kesempatan untuk tumbuh terhadap pengembangan karir PNS yang dinyatakan dalam presentase. Hasil analisis korelasi linier berganda dan determinasi dapat dilihat sesuai dengan Tabel 4.16 sebagai berikut :

\section{Analisis Korelasi Berganda dan Determinasi}

Sesuai tabel 4.16 di atas diperoleh hasil perhitungan untuk analisis korelasi berganda diperoleh nilai R sebesar 0,716 dan determinasi diperoleh nilai R Square sebesar 0,513 atau 51,3 persen.

\section{Analisis Uji F (F-test)}

1. Menentukan Formulasi Hipotesis 
Ho : $b_{1}, b_{2}, b_{3}, b_{4}, b_{5}=0$, berarti tidak ada hubungan positif yang nyata antara prestasi kerja, pendidikan, pengalaman kerja, pengenalan dan kesempatan untuk tumbuh terhadap pengembangan karir pegawai negeri sipil. Hi : $b_{1}, b_{2}, b_{3}, b_{4}, b_{5}>0$, berarti ada hubungan positif yang nyata antara prestasi kerja, pendidikan, pengalaman kerja, pengenalan dan kesempatan untuk tumbuh terhadap pengembangan karir pegawai negeri sipil.

2. Ketentuan pengujian

Dengan menggunakan derajat kepercayaan sebesar $95 \%$ dengan derajat bebas pembilang $\mathrm{K}=6$ dan derajat penyebut $\mathrm{n}-\mathrm{k}-1=54$, maka nilai $\mathrm{F}$ tabel $(5: 54)=2,4558$ $=2,45$

3. Kriteria pengujian

a. Jika F-hitung $\geq$ F-tabel maka Ho ditolak, berarti hubungan signifikan.

b. Jika F-hitung $\leq$ F-tabel maka Ho diterima, berarti hubungan tidak signifikan.

Tabel 4.17: Analisis Uji F-hitung ANOVA(b)

\begin{tabular}{|c|c|c|c|c|c|}
\hline \multicolumn{7}{|c|}{ ANOVA $^{\mathrm{b}}$} \\
\hline $\begin{array}{c}\text { Model } \\
\text { 1 Regression }\end{array}$ & $\begin{array}{c}\text { Sum of Squares } \\
242.387\end{array}$ & $\begin{array}{c}\mathrm{df} \\
5\end{array}$ & Mean Square & $\mathrm{F}$ & Sig. \\
\hline Residual & 230.171 & 55 & 48.477 & 11.584 & $.000^{\mathrm{a}}$ \\
\hline Total & 472.557 & 60 & 4.185 & & \\
\hline
\end{tabular}

a. Predictors: (Constant), Kesempatan untuk Tumbuh, Prestasi Kerja, Pengenalan, Pendidikan, Pengalaman Kerja

b. Dependent Variable: Pengembangan Karir Dari tabel di atas diperoleh hasil Fhitung sebesar 11,584.

Tabel 4.18: Analisis Regresi Linier Berganda, Uji Koefisien Betha dan Uji thitung Coefficients(a)

\begin{tabular}{|c|c|c|c|}
\hline \multicolumn{3}{|c|}{ Coefficients $^{\text {a }}$} \\
\hline & \multicolumn{2}{|c|}{$\begin{array}{c}\text { Standardized } \\
\text { Unstandardized } \\
\text { Coefficients Coefficients }\end{array}$} & \\
\hline Model & B & Std. Error Beta t & Sig. \\
\hline
\end{tabular}




\begin{tabular}{|c|c|c|c|c|}
\hline 1 & (Constant) & -4.785 & $3.947-1.212$ & .231 \\
\hline \multirow{4}{*}{$\operatorname{Pr}$} & Pestasi Kerja & .092 & .063 .1421 .478 & .145 \\
\cline { 2 - 5 } & Pendidikan & .266 & .113 .2502 .362 & .022 \\
\cline { 2 - 5 } & Pengalaman Kerja & .081 & .125 .070 .644 & .522 \\
\cline { 2 - 5 } & Pengenalan & .295 & .110 .3452 .669 & .010 \\
\cline { 2 - 5 } & $\begin{array}{c}\text { Kesempatan Untuk } \\
\text { Tumbuh }\end{array}$ & .246 & .118 .2312 .077 & .043 \\
\cline { 2 - 4 } & & & \\
\hline \multicolumn{3}{|c|}{ a. Dependent Variable: Pengembangan Karir } \\
\hline
\end{tabular}

Maka diperoleh persamaan garis regresi : $\mathrm{Y}=-4,785+0,092 \mathrm{X}_{1}+0,266 \mathrm{X}_{2}+$ $0,081 X_{3}+0,295 X_{4}+0,246 X_{5}$

Analisis Uji t (t-test)

Adapun langkah-langkah pengujiannya adalah sebagai berikut. (Sugiyono,2012:177).

1. Formulasi hipotesis

Ho : $b_{1}, b_{2}, b_{3}, b_{4}, b_{5}=0$, berarti tidak ada pengaruh yang positif dan signifikan secara parsial antara variabel prestasi kerja, pendidikan, pengalaman kerja, pengenalan dan kesempatan untuk tumbuh terhadap pengembangan karir PNS pada Dinas Ketentraman Ketertiban dan Satuan Polisi Pamong Praja Kota Denpasar. Hi : b1, b2, b3, b4, b5 $>0$, berarti ada pengaruh yang positif dan signifikan secara parsial antara variabel prestasi kerja, pendidikan, pengalaman kerja, pengenalan dan kesempatan untuk tumbuh terhadap pengembangan karir PNS pada Dinas Dinas Ketentraman Ketertiban dan Satuan Polisi Pamong Praja Kota Denpasar.

2. Ketentuan pengujian :

Dengan menggunakan derajat kepercayaan 95\% atau tingkat kesalahan 5\% ( $\alpha=5 \%$ ) dan derajat kebebasan $(\mathrm{n}-\mathrm{k}-1)$, tes pada satu sisi pada sisi kanan maka diperoleh nilai t-tabel $(0,05: 54)=1,671$

3. Kriteria penilaian

4. Jika t-hitung $<$ t-tabel $(1,671)$ maka Ho ditolak, berarti pengaruh signifikan Jika thitung $>$ dari t-tabel $(1,671)$ maka Ho diterima, berarti pengaruh tidak signifikan. 
Berdasarkan hasil analisis pada Tabel 4.18 dapat diketahui nilai thitung dan angka signifikansi dari masing-masing variabel bebas. Variabel prestasi kerja $\left(\mathrm{X}_{1}\right)$ memiliki nilai t-hitung sebesar 1,478 dengan signifikansi 0,145. Variabel pendidikan $\left(\mathrm{X}_{2}\right)$ mempunyai nilai t-hitung sebesar 2,362 dengan signifikansi 0,022. Variabel pengalaman kerja (X3) memiliki t-hitung sebesar 0,644 dengan signifikansi 0,522. Variabel pengenalan $\left(\mathrm{X}_{4}\right)$ memiliki t-hitung sebesar 0,345 dengan signifikansi 0,010 dan variabel kesempatan untuk tumbuh memiliki nilai t-hitung sebesar 2,077 dengan signifikansi 0,043. Jadi dapat disimpulkan bahwa dari lima variabel yang diperkirakan hanya variabel pengenalan dan kesempatan untuk tumbuh yang signifikan berpengaruh secara parsial terhadap pengembangan karir PNS pada Dinas Ketentraman Ketertiban Dan Satuan Polisi Pamong Praja Kota Denpasar.

\section{Uji Koefisien Betha}

Untuk menjawab permasalahan keempat dalam penelitian ini yaitu untuk melihat variabel bebas yang berpengaruh dominan terhadap variabel terikat digunakan uji koefisien betha yang terbesar dan hasilnya dapat dilihat pada tabel 4.18 diatas sehingga dapat disimpulkan bahwa pengenalan merupakan variabel dominan yang mempengaruhi pengembangan karir pegawai negeri sipil pada Dinas Ketentraman Ketertiban dan Satuan Polisi Pamong Praja Kota Denpasar yaitu dengan nilai beta standardized 0,345 atau sebesar 34,5 persen.

\section{KESIMPULAN}

Berdasarkan analisis dan pembahasan hasil penelitian pada bab terdahulu, dapat diambil simpulan sebagai berikut.

1. Variabel prestasi kerja, pendidikan, pengalaman kerja, pengenalan dan

2. kesempatan untuk tumbuh secara simultan mempunyai pengaruh positif yang signifikan terhadap pengembangan karir pegawai negeri sipil pada kantor Dinas Ketentraman Ketertiban dan Satuan Polisi Pamong Praja.

3. Dari kelima variabel yang mempengaruhi pengembangan karir pegawai negeri sipil pada kantor Dinas Ketentraman Ketertiban dan Satuan Polisi Pamong Praja hanya 
variabel pendidikan, pengenalan dan kesempatan untuk tumbuh yang secara parsial mempunyai pengaruh positif yang signifikan terhadap pengembangan karir pegawai negeri sipil pada kantor Dinas Ketentraman Ketertiban dan Satuan Polisi Pamong Praja.

4. Variabel pengenalan adalah variabel yang dominan berpengaruh terhadap pengembangan karir pegawai negeri sipil pada kantor Dinas Ketentraman Ketertiban dan Satuan Polisi Pamong Praja yakni sebesar 34,5 persen.

\section{DAFTAR PUSTAKA}

Aurathai, Lertwannawit., Serirat Sirivan., and Pholpantin Siroj. 2009. Career Competencies And Career Success Of Thai Employees In Tourism And Hospitality Sector. The International Business \& Economics Research Journal. vol 8. no: 11. pp. $65-72$.

Crowley,Marian., and Henry. 2012. Re-Conceptualizing The Career Development Of Self Iniated Expatriates: Rivers Not Ladders. Journal Of Management Development: vol 31. no: 2.pp 130-141.

Ghozali, Imam. 2007. Aplikasi Analisis Multivariate dengan Program SPSS. Semarang : Badan Penerbit Universitas Diponegoro.

Gouzali Saydam, 2005. Manajemen Sumber Daya Manusia, Krisna Prima Persada, Yogyakarta.

Harlie, M. 2010. Pengaruh Displin Kerja, Motivasi Dan Pengembangan karir Terhadap Kinerja Pegawai Negeri Sipil Pada Pemerintah Kabupaten Tabalong Di Tanjung Selatan.Kalimatan Selatan.Jurnal.Sekolah Tinggi Ilmu Adminitrasi (STIA) Tabalong Kalimantan.

Li, Jessica., and Ronald K. Yeo. 2011. Quality Of Work Life And Career Development:Perceptions Of Part-Time MBA Students. Journal Employee Relations: vol 33. No: 3. pp 201-220.

Lewtney, Barbara, and Fransisca Carter. 2010. Career Development Project For Incarcerated Youth: Preparing For The Future. The Journal Of Correctional Education: vol 15. No. pp 110-118. 
Muis, Mahlia. 2009. Analisis Faktor-Faktor Yang Mempengaruhi Pengembangan Karir Karyawan Perbankan Di Kota Makassar.Jurnal.Fakultas Ekonomi Universitas Hasanudin.Makassar.

Maxwell,Grillian. 2009. Mentoring For Enchacing Females's Career Development:The Bank Job. Journal Equal Opportunities International: vol.28.no: 7.pp 561-576.

Perdana, Dika Yudha. 2011. Pengaruh Motivasi Kerja, Kepemimpinan dan Kesempatan Pengembangan Karir Terhadap Kinerja Karyawan Di PT. Nyonya Meneer Semarang.Semarang.Skripsi.Fakultas Ekonomi Universitas Diponegoro Semarang.

Perdana, Dika Yudha. 2011. Pengaruh Motivasi Kerja, Kepemimpinan dan Kesempatan Pengembangan Karir Terhadap Kinerja Karyawan Di PT. Nyonya Meneer Semarang.Semarang.Skripsi.Fakultas Ekonomi Universitas Diponegoro Semarang.

Riduwan dan Sunarto, 2007. Pengantar Statistik Untuk Penelitian Pendidikan, Sosial, Ekonomi dan Bisnis, Afabeta, Bandung.

Rosyawati, A.A. Sagung. 2007. Analisis Beberapa Faktor Yang Mempengaruhi Pengembangan Karir Pejabat Perempuan di Pemerintah Provinsi Bali. Tesis Fakultas Ekonomi Program Magister Manajemen Universitas Udayana.

Septyawati, Nise. 2009. Analisis Pengembangan Karir Pengaruhnya Terhadap Kepuasan Kerja Karyawan Pada Kantor Pusat PT. Pos Indonesia (Persero) Bandung. Jurnal. Universitas Komputer Indonesia.

Sugiyono, 2012. Metode Penelitian Bisnis, Alfabeta, Bandung

Sutrisno Edy, 2009. Manajemen Sumber Daya Manusia, Kencana, Jakarta.

Veithzal Rivai, 2011. Manajemen Sumber Daya Manusia untuk Perusahaan, Raja Grafindo Persada, Jakarta. 